\title{
Sources, Distribution and Toxicity of Polycyclic Aromatic Hydrocarbons (PAHs) in Particulate Matter
}

\author{
Byeong-Kyu Lee and Van Tuan $\mathrm{Vu}$ \\ Department of Civil and Environmental Engineering, University of Ulsan
}

Korea

\section{Introduction}

Polycyclic aromatic hydrocarbons (PAHs) are a group of organic compounds consisting of two or more fused aromatic rings. PAHs originate mainly from anthropogenic processes, particularly from incomplete combustion of organic fuels. PAHs are distributed widely in the atmosphere. Natural processes, such as volcanic eruptions and forest fires, also contribute to an ambient existence of PAHs. PAHs can be present in both particulate and gaseous phases, depending upon their volatility. Light molecular weight PAHs (LMW PAHs) that have two or three aromatic rings are emitted in the gaseous phase, while high molecular weight PAHs (HMW PAHs), with five or more rings, are emitted in the particulate phase. In the atmosphere, PAHs can undergo photo-degradation and react with other pollutants, such as sulfur dioxide, nitrogen oxides, and ozone.

Due to widespread sources and persistent characteristics, PAHs disperse through atmospheric transport and exist almost everywhere. Human beings are exposed to PAH mixtures in gaseous or particulate phases in ambient air. Long-term exposure to high concentrations of PAHs is associated with adverse health problems. Since some PAHs are considered carcinogens, inhalation of PAHs in particulates is a potentially serious health risk linked to an excess risk of lung cancer. Thus, studies on PAHs in particulate matter (PM), such as PM10 and PM2.5 in ambient air, have become attention greater focus of research in recent years.

\section{Physical and chemical characteristics of PAHs}

PAHs are a group of several hundred individual organic compounds which contain two or more aromatics rings and generally occur as complex mixtures rather than single compounds. PAHs are classified by their melting and boiling point, vapor pressure, and water solubility, depending on their structure. Table 1 shows physical and chemical characteristics of 16 priority PAHs, listed by the US EPA. Most PAHs, especially as molecular weight increases, are soluble in non-polar organic solvents and are barely soluble in polar water.

Most PAHs are persistent organic pollutants (POPs) in the environment. Many of them are chemically inert. However, PAHs can be photochemically decomposed under strong 
ultraviolet light or sunlight, and thus some PAHs can be lost during atmospheric sampling. Also, PAHs can react with ozone, hydroxyl radicals, nitrogen and sulfur oxides, and nitric and sulfuric acids, which affect the environmental fate or conditions of PAHs.

\section{Sources and Emission of PAHs}

PAHs are mainly derived from anthropogenic activities related to pyrolysis and incomplete combustion of organic matter. Emission sources of PAHs affect their characterization and distribution, as well as their toxicity. In this book, the major sources of PAH emissions may be divided into four classes: stationary sources (including domestic and industrial sources), mobile emissions, agriculture activities, and natural sources.

\subsection{Stationary sources}

\subsubsection{Domestic sources}

Heating and cooking are dominant domestic sources of PAHs. The burning and pyrolysis of coal, oil, gas, garbage, wood, or other organic substances are the main domestic sources. Domestic sources are important contributors to the total emissions of PAHs in the environment. Differences in climate patterns and domestic heating systems produce large geographic variations in domestic emissions. PAH emissions from these sources may be a major health concern because of their prevalence in indoor environments (Ravindra et al., 2006). According to a recent World Health Organization (WHO) report, more than $75 \%$ of people in China, India, and South East Asia and 50-75\% of people in parts of South America and Africa use combustion of solid fuels, such as wood, for daily cooking.

Main indoor PAH sources are cooking and heating emissions and infiltration from outdoors. PAHs emissions from cooking account for $32.8 \%$ of total indoor PAHs (Zhu et al., 2009). LMW PAHs which originate from indoor sources are the predominant proportion of the total PAHs identified in residential non-smoking air. Toxicity of PAH mixtures from indoor sources is lower than mixtures which contain large amounts of HMW PAHs. Cigarette smoke is also a dominant source of PAHs in indoor environments. In many studies, PAHs in the indoor air of smoking residences tend to be higher than those of non-smoking residences. 


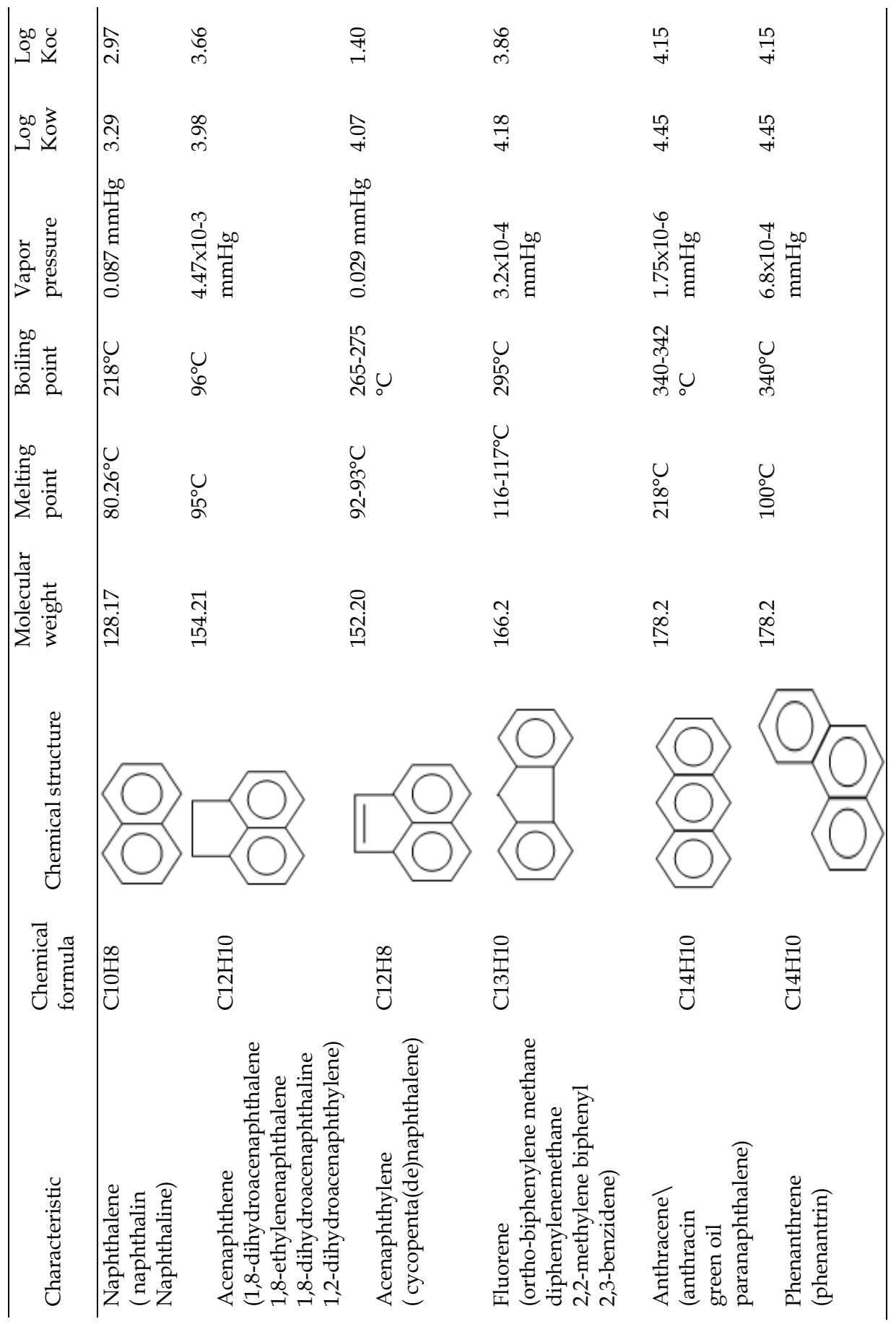


Fluoranthene

(benzo(j,k)fluorine

1,2-(1,8-naphthylene)

benzene

1,2-benzacenaphthene)

Pyrene

(benzo(d,e,f)phenanthrene)

Benzo(a)anthracene

(benz(a)anthracene

1,2-benzanthracene

benzo(b)phenanthrene

2,3-benzophenanthrene

Tetraphene)

Chrysene

(benzo(a)phenanthrene

1,2-benzphenanthrene)

Benzo(b)fluoranthene

(2,3-Benzfluoranthen

2,3-benzofluoranthene

3,4-benz(e)acephenathrylene 3,4-benzfluoranthene benz(e)fluoranthene)
$\mathrm{C} 16 \mathrm{H} 10$

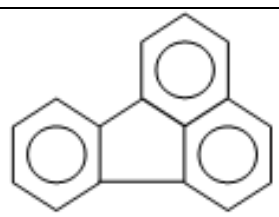

$\mathrm{C} 16 \mathrm{H} 10$<smiles></smiles>

202.3

228.29<smiles>c1ccc2cc3c(ccc4ccccc43)cc2c1</smiles>

$\mathrm{C} 18 \mathrm{H} 12$<smiles>c1ccc2c(c1)ccc1c3ccccc3ccc21</smiles>

228.28

C20H12

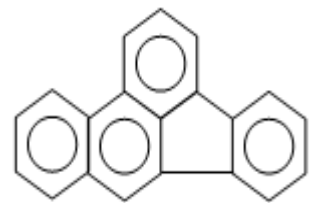

$254^{\circ} \mathrm{C}$

$448^{\circ} \mathrm{C}$

$393-404$ ${ }^{\circ} \mathrm{C}$

$438^{\circ} \mathrm{C}$

$158^{\circ} \mathrm{C}$

o dat 
Benzo(k)fluoranthene

(8,9-benzofluorathene

11,12-benzo[k]fluoranthene benzo(k)fluoranthene

2,3,1',8'-binapthylene)

Benzo(a)pyrene

(1,2-benzopyrene

6,7-benzopyrene

B(a)P, BP

3,4-benzopyrene

benzo $(\mathrm{d}, \mathrm{e}, \mathrm{f})$ chrysene

3,4-benzpyrene)

Dibenzo(a,h)anthracene

(1,2:5,6-benzanthracene

1,2:5,6-dibenzanthracene dibenzo(a,h)anthracene

DBA, 1,2,5,6-DBA)

Benzo(g,h,i)perylene

(1,12-benzoperylene)

Ideno(1,2,3-c,d)pyrene

(Idenopyrene

ortho-phenylene pyrene

1,10-(1,2-phenylene) pyrene

2,3-ortho-phenylene pyrene)
$\mathrm{C} 20 \mathrm{H} 12$

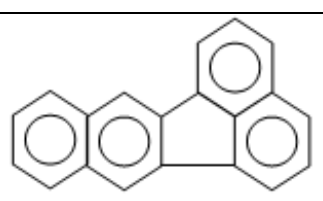

$\mathrm{C} 20 \mathrm{H} 12$<smiles>c1ccc2c(c1)cc1ccc3cccc4c3c2c14</smiles>

252.3

179-179.3

$495^{\circ} \mathrm{C}$

${ }^{\circ} \mathrm{C}$

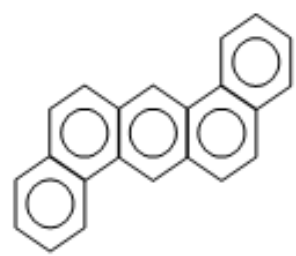

$\mathrm{C} 22 \mathrm{H} 12$

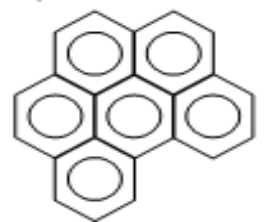

278.35

$262^{\circ} \mathrm{C}$

No dat

C22H14

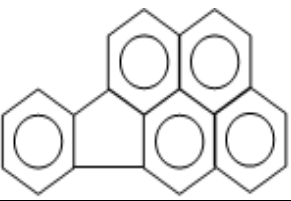

276.34

$273^{\circ} \mathrm{C}$

$550^{\circ} \mathrm{C}$

276.3

$163.6^{\circ} \mathrm{C}$

$530^{\circ} \mathrm{C}$

1 Table 1. Physical and chemical characteristics of some popular PAHs (US EPA, 1995; ATSDR, 1995) 
Liu et al. (2008) reported that coal stoves are still widely used for cooking and heating in rural North China. Total emission factors (EFs) for 15 PAHs ranged from 52.8 to 1434.8 $\mathrm{mg} / \mathrm{kg}$, depending on the drying status and compositions of raw coals used for cooking and heating. Chen et al. (2004) found a large decrease in the EFs of PAHs from residences with coal stoves that burned honeycomb coal briquettes. Emission factors of 17 PAHs and 10 genotoxic PAHs, based on a coal-weight basis were 111.65 and $18.41 \mathrm{mg} / \mathrm{kg}$, respectively. This indicates a twenty-fold decrease in EFs, as compared to those from cooking and heating with raw coal. Oanh et al. (1999) investigated EFs from wood fuel, charcoals, and coal briquettes in a stove for domestic combustion. They found that wood fuel burning released the highest emissions of 18 PAHs and 11 genotoxic PAHs in terms of EFs, accounting for energy (mg/MJ) emission rates and based on the pollutant concentrations in smoke. Charcoal released the lowest amount of PAH emissions. On a fuel-weight basis, wood fuel burning has the same EF as coal briquette burning $(110 \mathrm{mg} / \mathrm{kg})$. However, emissions of genotoxic PAHs from wood burning were twice as high as those from charcoal burning.

\subsubsection{Industrial sources}

PAH emissions from industries are produced by burning fuels such as gas, oil, and coal. PAHs can also be emitted during the processing of raw materials like primary aluminum. Sources of PAHs include emissions from industrial activities, such as primary aluminum and coke production, petrochemical industries, rubber tire and cement manufacturing, bitumen and asphalt industries, wood preservation, commercial heat and power generation, and waste incineration.

Chen et al. (2007) studied emissions of PAHs from the pyrolysis of scrap tires. Total PAH emissions from a scrap tire plant via pyrolysis were $42.3 \mathrm{~g} /$ day with an EF of $4 \mathrm{mg} / \mathrm{kg}$. To study the thermal degradation of organic materials, Fabbri et al. (2006) investigated PAH emissions from pyrolysis products. EFs of PAHs from thermal decompositions of organic materials ranged from $0.4 \pm 0.13 \mathrm{mg} / \mathrm{g}$ for cellulose to $9.0 \pm 0.5 \mathrm{mg} / \mathrm{g}$ for tyre. Yang et al. (2005) reported that EFs average $71.0 \mathrm{mg} / \mathrm{g}$ from joss paper furnaces. With applied air pollution control devices, such as adsorption towers, removal efficiencies of total PAHs are $42.5 \%$ and $11.7 \%$ for particulate and gaseous PAHs, respectively.

Yang et al. (1998) reported emissions of PAHs from various industrial stacks: a blast furnace, a basic oxygen furnace, a coke oven, an electric arc furnace, a heavy oil plant, a power plant, and a cement plant. The coke oven, electric arc furnace, and heavy oil combustor produced large amounts of HMW PAH emissions. EFs of PAHs from these industrial stacks ranged from 0.08 to $3.97 \mathrm{mg} / \mathrm{kg}$ feedstock, while EFs for BaP ranged from 1.87 to $15.5 \mu \mathrm{g} / \mathrm{g}$ feedstock. The highest EFs of total PAHs and BaP were found from the combustion of heavy oils.

Recently, PAH emissions from waste incineration have been investigated in many studies. According to the Italia Agency for Environmental Protection, total EFs of PAHs ranged from 91 to $414 \mu \mathrm{g} / \mathrm{g}$ of waste burned in incinerators of municipal and industrial wastes. Lee et al. (2002) estimated that EFs from two batch-type medical waste incinerators: a mechanical grate (MG- MWI) and a fixed rate (FG-MWI). EFs of total PAHs were 252 and 856 $\mathrm{mg} / \mathrm{kg}$-waste for MG-MWI and FG-MWI, respectively. EFs for medical waste incinerators were consistently much higher than those for municipal waste incinerators (871 $\mu \mathrm{g} / \mathrm{kg}$-waste) operated in the same city. Air pollution control devices remove PAHs with efficiencies higher than $78 \%$ for PAHs with four or more rings, but had efficiencies lower than $5 \%$ for LMW PAHs with two or three rings. 


\subsection{Mobile sources}

Mobile sources are major causes of PAH emissions in urban areas. PAHs are mainly emitted from exhaust fumes of vehicles, including automobiles, railways, ships, aircrafts, and other motor vehicles. PAH emissions from mobile sources are associated with use of diesel, coal, gasoline, oils, and lubricant oil. Exhaust emissions of PAHs from motor vehicles are formed by three mechanisms: 1) synthesis from smaller molecules and aromatic compounds in fuel; 2) storage in engine deposits and in fuel; and 3) pyrolysis of lubricant (Baek et al., 1991). One of the major influences on the production of PAHs from gasoline automobiles is the air-to-fuel ratio. It has been reported that the amount of PAHs in engine exhaust decreases with leaner mixtures (Ravindra et al., 2006).

A main contributor to PAH concentrations in road dust as well as urban areas is vehicle exhaust. Abrantes et al. (2009) reported that total emissions and toxicities of PAHs released from light-duty vehicles using ethanol fuel are less than those using gasohol. For example, in ethanol vehicles, total EFs of PAHs ranged from 11.7 to $27.4 \mu \mathrm{g} / \mathrm{km}$. In gasohol vehicles, total EFs ranged from 41.9 to $612 \mu \mathrm{g} / \mathrm{km}$. EFs for BaP toxicity equivalence varied from 11.7 to $21.8 \mathrm{ng}$ TEQ/ $\mathrm{km}$ for ethanol vehicles and from 9.84 to $4,610 \mathrm{ng}$ TEQ/ $\mathrm{km}$ for gasohol vehicles. LMW PAHs are the dominant PAHs emitted from light-duty vehicles. According to the report of PAH emissions from vehicles by Abrantes et al. (2004), total EFs of PAHs from the exhaust of light-duty diesel vehicles ranged from 1.133 to $5.801 \mathrm{mg} / \mathrm{km}$ with emissions dominated by LWM PAHs. EFs reported for heavy-duty vehicles (MSC-E, 2001) and light-duty vehicles were $11.4-82.1 \mu \mathrm{g} / \mathrm{km}$ and $28.2 \mu \mathrm{g} / \mathrm{km}$, respectively.

Yang et al. (2005) reported that EFs of total PAH emissions from a 2-stroke carburetor (2-Stk/Cb), 4-stroke carburetor (4-Stk/Cb), and 4-stroke fuel injection (4-Stk/FI) motorcycles were $8.320,5.990$ and $3.390 \mathrm{mg} / \mathrm{km}$, respectively. The EFs of total BaP equivalent are $10.8 \mu \mathrm{g} / \mathrm{km}$, indicating that most of the PAHs exhausted from the 2-Stk/ Cb motorcycle are carcinogenic. Spezzano et al. (2008) reported that EFs of total PAHs (18 PAHs) ranged from 1.790 to $15.059 \mathrm{mg} / \mathrm{km}$, and EFs of benzo(a)pyrene equivalent (BaPeq) ranged from 4.7 to $86.3 \mu \mathrm{g} / \mathrm{km}$ for two-stroke $50-\mathrm{cm}^{3}$ mopeds. Two-stroke mopeds with small engines emit comparable or even more PAHs than emissions reported from gasolineand diesel-powered passenger cars and light- and heavy-duty vehicles.

Chen et al. (2006) reported that EFs of total PAHs and total BaPeq for the UH-1H helicopter turboshaft engine $(63.4$ and $0.309 \mathrm{mg} / \mathrm{L}-$ fuel) are 1.65-23.4 and 1.30-7.54 times higher, respectively, than those for the motor vehicle engine, heavy-duty engine, and F101 aircraft engine. LMW PAHs are the dominant PAHs emitted from helicopter engines, accounting for 97.5\% of the total PAH emissions.

Fuel type has a substantial effect on EFs and toxicity of PAHs from vehicle engines. He et al. (2010) indicated that diesel engines using diesel/biodiesel and their blends can greatly reduce total emissions of PAHs by 19.4 and 13.1\%, respectively. The BaP TEQ of PAHs emitted also decreased $15 \%$ with the use of biodiesel.

\subsection{Agricultural sources}

Open burning of brushwood, straw, moorland heather, and stubble are agricultural sources of PAHs. All of these activities involve burning organic materials under suboptimum combustion conditions. Thus, it is expected that a significant amount of PAHs are produced from the open burning of biomass. 
Emission factors of PAHs from wood combustion ranged from 16.4 to 1,282 mg/kg wood (Jenkins et al., 1996; Oanh et al., 1999; Schauer et al., 2001). PAH concentrations released from wood combustion depend on wood type, kiln type, and combustion temperature. $80-90 \%$ of PAHs emitted from biomass burning are LMW PAHs, including naphthalene, acenaphthylene, phenanthrene, flouranthene and pyrene.

$\mathrm{Lu}$ et al. (2009) reported that PAHs emitted from the open burning of rice and bean straw are influenced by combustion parameters. Total emissions of 16 PAHs from the burning of rice and bean straw varied from 9.29 to $23.6 \mu \mathrm{g} / \mathrm{g}$ and from 3.13 to $49.9 \mu \mathrm{g} / \mathrm{g}$, respectively. $\mathrm{PAH}$ emissions increased with increasing temperatures from 200 to $700{ }^{\circ} \mathrm{C}$. Maximum emissions of PAHs were observed at $40 \% \mathrm{O}_{2}$ content in supplied air. However, emissions of PAHs released from the open burning of rice straw negatively correlate with the moisture content in the straw.

\subsection{Natural sources}

Accidental burning of forests, woodland, and moorland due to lightning strikes are natural sources of PAHs. Furthermore, volcanic eruptions and decaying organic matter are also important natural sources, contributing to the levels of PAHs in the atmosphere. The degree of $\mathrm{PAH}$ production depends on meteorological conditions, such as wind, temperature, humidity, and fuel characteristics and type, such as moisture content, green wood, and seasonal wood.

\subsection{Emission factors and inventory}

Emission factors (EFs) of PAHs from different sources are given in Table 2. The EF data of PAHs are useful for estimating the amount of PAHs released from processes, including combustion, open burning, and pyrolysis. Atmospheric emission inventories of PAHs from certain sources or processes are obtained from an emission estimate using PAH EFs of various sources, using the following formula:

Emission of PAHs $=\Sigma\left(\right.$ Activity Level $\left._{i}\right) \times \mathrm{EF}_{i} \times\left(1-\frac{\text { Control Efficiency }_{i}}{100}\right)$

Thus, the difference between measured values and reported or estimated values of EFs is a major limitation of PAH inventory construction. Recently, PAH emission inventories have been developed in several countries and have shown that combustion is a major source of PAHs. Combustion of biofuel contributed to $56.7 \%$ of total sixteen priority PAHs on a global basis in 2004 (Yang and Tao, 2009). Table 3 shows emission inventories of PAHs on a global scale and for some countries based on emissions in 2003 and 2004. 


\begin{tabular}{|c|c|c|c|}
\hline Emissions source & $\begin{array}{c}\text { Emission } \\
\text { Factor } \\
(\mathrm{mg} / \mathrm{kg}) \\
\end{array}$ & PAHs & References \\
\hline Wood combustion & $16.4-1,282$ & total PAHs & Schauer et al., 2001 \\
\hline Rice burning & $9.29-23.6$ & 16 PAHs & Lu et al., 2009 \\
\hline Bean burning & $3.13-49.9$ & 16 PAHs & - \\
\hline Wood and root fuel & $5.3-13.2$ & $\mathrm{~B}[\mathrm{a}] \mathrm{P}$ & Gupta et al., 1998 \\
\hline Two-stroke fuel-no catalyst & 0.021 & 6 PAHs & Gambino et al., 2000 \\
\hline Two-stroke fuel-with catalyst & 0.014 & - & - \\
\hline Oil-burner-boiler combination & 0.005 & $\mathrm{~B}[\mathrm{a}] \mathrm{P}$ & IPCS, 1998 \\
\hline Barbecue briquettes & $2.5-13$ & total PAHs & - \\
\hline Soot open fire & $3-240$ & $\mathrm{~B}[\mathrm{a}] \mathrm{P}$ & - \\
\hline Boilers using heavy oil & 0.013 & total PAHs & Li et al., 1999 \\
\hline Boilers using diesel & 0.3 & - & - \\
\hline Feed-stock & $0.077-3.970$ & total PAHs & Yang et al., 1998 \\
\hline Feed-stock & $0.002-0.016$ & $\mathrm{~B}[\mathrm{a}] \mathrm{P}$ & - \\
\hline Coal charged & 15 & Total PAHs & IPCS, 1998 \\
\hline- & 0.02 & $\mathrm{~B}[\mathrm{e}] \mathrm{P}$ & - \\
\hline Aluminum production & $4.4 \mathrm{~kg} /$ tons & total PAHs & - \\
\hline- & $0.11 \mathrm{~kg} /$ tons & $\mathrm{B}[\mathrm{a}] \mathrm{P}$ & - \\
\hline Bituminous coal & 70.2 & total PAHs & Chen et al., 2005 \\
\hline Scrap tire pyrolysis plant & 4 & - & Chen et al., 2007 \\
\hline Honeycomb briquette & 56.94 & - & Oanh et al., 1999 \\
\hline Open burning biomass fuels & $5-683$ & 19 PAHs & Jenkins et al., 1996 \\
\hline
\end{tabular}

Table 2. The emission factors (EFs) of PAHs from the different sources

Major emissions of PAHs in developing countries, such as China, India, Brazil, and Sudan, are associated with biomass burning, including use of biofuel and wild savanna fire. In particular, total emissions of PAHs from China and India were almost $40 \%$ of the global total emissions. However, emission features in developed countries, such as USA and UK, are quite different from those in developing countries. For example, PAH emissions in the USA are mainly associated with emissions from the use of consumer products, vehicles exhaust, and waste incinerators. The largest emissions of PAHs in UK are from traffic, followed by wood burning. 


\begin{tabular}{|c|c|c|c|c|c|c|c|}
\hline Sources & Global & USA & China & India & Brazil & Sudan & UK \\
\hline Biofuel & 56.7 & 9.1 & 66.4 & 92.5 & 17.7 & 28.1 & \\
\hline Wild fire & 17 & 3.3 & & & 66 & & \\
\hline Savanna fire & & & & & 4.5 & 69.7 & \\
\hline Firewood & & & & & & & 15.5 \\
\hline Open straw burning & & & 2 & 3.2 & 1.2 & & 4.3 \\
\hline Consumer products & 6.9 & 35.1 & 0.9 & 0.6 & 2.5 & & \\
\hline Traffic oil & 4.8 & 23 & 2 & & 3 & & 58.2 \\
\hline Other oil & & & & & & & 1.9 \\
\hline Domestic Coal & 3.7 & & 10.7 & 1.3 & & & \\
\hline Industrial Coal & & & & & & & 1.7 \\
\hline Coke Industry & 3.6 & & 14.4 & & 0.6 & & 3.8 \\
\hline Petrol refining & 2.4 & 8.7 & 1 & & 1.7 & & \\
\hline Waste incineration & 1.9 & 9.5 & & & & & \\
\hline Gasoline distribution & & 3 & & & & & \\
\hline Areospace industry & & 2.5 & & & & & \\
\hline Al electron & 1.4 & 1.9 & & & 2.2 & & 4.8 \\
\hline Other industry & & & & & & & 5.7 \\
\hline Others & 1.5 & 3.9 & 2.7 & 2.3 & 0.7 & 2.2 & 5.2 \\
\hline Total (gigatons) & 530 & 32 & 114 & 90 & 19 & 5 & \\
\hline Year & 2004 & 2004 & 2004 & 2004 & 2004 & 2004 & 2003 \\
\hline
\end{tabular}

Table 3. The emission inventories of PAHs for global and some countries (Yang \& Tao, 2009)

\section{Sampling and analytical methods}

\subsection{PAH sampling equipment}

Due to the volatility of PAHs, released PAHs can be associated with the particulate and/or vapor phase. LMW PAHs are released in a vapor phase into the environment, while HMW PAHs containing five or more rings are adsorbed onto suspended particular matter. These physical states of PAHs influence collection efficiency and selection of the sampling apparatus of PAHs. PAHs in the atmosphere are mainly collected by two sampling models: active sampling and passive sampling.

Active samplers include high-volume, low-volume, and impingement cascade samplers. A sorbent, filter, and plug are among the implements usually used to collect PAHs in the active sampling mode. Active sampling utilizes deposition or adsorption of target PAH compounds on filters or sorbent materials, through the collection of air particulates onto filters or into sorbent tubes, using a pump. PAHs accumulated on filters or sorbent materials are returned to the laboratory for analysis. In many applications, filters such as quartz fiber filters, glass fiber filters and cellulose filters are used to collect PAHs associated with particulate matter. These filters are highly vulnerable to losing the collected PAHs via 
volatilization and thus precautions need to be taken to minimize the loss of LMW PAHs. For collecting gaseous PAHs, commonly used sorbents include XAD-2 resin and polyurethane foam (PUF) due to their high collection efficiencies, chemical stability, easy extractability and low cost.

However, drawbacks for active sampling include very high costs of samplers and the loss or volatilization of PAHs during the sampling and handing process. "These disadvantages can be alleviated by using passive sampling methods, which are based on free flow of analyte molecules from the sampled medium to a collecting medium as a result of differences in chemical potentials" (Caslavsky et al., 2004). Passive sampling has been widely applied for ambient monitoring over broad areas. There are many sampling devices which have been successfully used for passive sampling of PAHs. Semipermeable membrane devices (SPMDs) have been reported as the most used devices for passive sampling.

There are three basic active sampling models of PAHs associated with particulate collection equipment:

1. PUF samplers: used for sampling PAHs in both total suspended particulate (TSP) and vapor phases.

2. High-volume samplers (Tisch sampler, PQ 200 sampler): used for sampling PAHs in $\mathrm{PM}_{10}$ and $\mathrm{PM}_{2.5}$.

3. Cascade impactor (3,4 and 9-stages): used for sampling PAHs in different size particles.

Sampling times are restricted to $24 \mathrm{~h}$ to minimize degradation and loss (volatilization) of collected PAHs. Reduced sampling times and flow rates in the collection of vapor PAHs is important. The use of an annular diffusion denuder, such as an oxidant denuder, with the filter systems minimizes PAH losses during sampling.

\subsection{Pretreatment of air samples}

Before sampling, filters must be wrapped separately in aluminum foil and baked in a muffle furnace at a temperature of $450^{\circ} \mathrm{C}$ for $6 \mathrm{~h}$. After sampling, they are kept under refrigeration at low temperatures to protect them from thermal degradation or loss by volatilization. Sorbents also need to be preserved carefully. XAD-2 resins and PUF plugs need to be cleaned by Soxhlet or ultrasonic methods before they are used for sampling (Lee and Lee, 2004).

\subsection{Extraction, concentration and analysis of PAHs}

After sampling, PAHs are extracted using organic solvents such as mixtures of n-hexane and dichloromethane. The extracted PAHs solutions need to be concentrated for analysis because PAHs are not as easily detected at low concentrations. To get sufficient detection and concentration analyses of PAHs from the collection medium, this chapter is limited to the following four major types of sample extraction techniques:

1. Soxhlet extraction

2. Ultrasonic extraction

3. Supercritical fluid extraction (SPE)

4. Accelerated solvent extraction (ASE)

Concentration methods popularly used to concentrate extracted PAH samples are rotary evaporators and K-D evaporators. For qualitative and quantitative analysis of extracted 
PAHs, gas chromatography, combined with mass spectrometry (GC-MS) or high performance liquid chromatography (HPLC), are often used. Recent studies of extraction, concentration, and analysis of PAHs in particulates are summarized in Table 4.

\section{Typical urban and rural concentrations of PAHs}

In general, concentrations of total PAHs are easily affected by locational and seasonal variations. Table 5 shows concentrations of total PAHs in urban and rural areas of different regions based on a recent literature survey. Average PAH concentrations (both gaseous and particle-bound PAHs) were highest in winter and lowest in summer due to higher energy consumption for heating and engine operation of vehicles and facilities during the cold seasons. Traffic exhaust and domestic coal combustion are main contributors of PAHs in urban areas, while biomass and domestic coal combustion are the predominant PAH sources in rural areas. Sources of PAHs in both urban and rural areas can be derived from industrial areas by the transport of PAHs through the atmosphere.

Liu et al. (2008) reported that urban PAH emissions (motor vehicle and coke production) are higher than rural emissions (primarily firewood and straw burning for cooking and heating) in spring, summer, and fall. However, winter PAH emissions in rural areas were much higher than those in urban areas due to of the abundance of coal, straw, and firewood burning for indoor heating in rural residences and for disposal of agricultural residues.

\begin{tabular}{llcll}
\hline Country & Area & SPAHs & $\begin{array}{l}\text { PAHs conc. } \\
\mathrm{ng} / \mathrm{m}^{3}\end{array}$ & References \\
\hline North Chinese Plain & urban & 10 & $870 \pm 330$ & Liu et al., 2008 \\
- & rural & - & $710 \pm 330$ & - \\
Flanders, Belgium & rural & 16 & 114 & Ravindra et al., 2006 \\
Seoul, Korea & urban & 16 & $89 \pm 74.3$ & Park et al., 2002 \\
Chicago, USA & urban & 16 & $13-1865$ & Li et al., 2005 \\
New Delhi, India & urban & 12 & $668 \pm 399$ & Sharma et al., 2007 \\
- & - & - & $672 \pm 388$ & - \\
London, UK & urban & 15 & 166 & Halsal et al., 1994 \\
Cardif, UK & urban & 15 & 59 & - \\
Campo Grande, Brazil & Campus & 14 & $8.94-62.5$ & Poppi and Silva, 2005 \\
Tai Chung, Taiwan & urban & 21 & $220 \pm 520$ & Fang et al., 2004 \\
- & rural & - & $831 \pm 427$ & - \\
- & industry & - & $1650 \pm 1240$ & - \\
Brisbane, Australia & urban & 16 & $0.4-19.73$ & Lim et al., 2005 \\
\hline
\end{tabular}

Table 5. Concentration of PAHs in various cities 


\begin{tabular}{|c|c|c|c|}
\hline Analyte & Pretreatment method & $\begin{array}{l}\text { Analytical } \\
\text { method }\end{array}$ & Reference \\
\hline 15-PAHs & $\begin{array}{l}\text { Soxhlet- Warm extraction method, rotary } \\
\text { evaporation }\end{array}$ & HPLC-FLD & $\begin{array}{l}\text { Okuda et al., } \\
2010\end{array}$ \\
\hline 15 EPA- AHs & $\begin{array}{l}\text { RS- fluorescence detection } \\
\text { ASE extraction (hydrometric), evaporate } \\
\text { concentration } \\
\text { Ultrasonic extraction with }\end{array}$ & GC-MS & $\begin{array}{l}\text { Li et al., } \\
2009 \\
\text { Lee and }\end{array}$ \\
\hline \multirow[t]{2}{*}{16 EPA-PAHs } & dichloromethane/n-hexan (1:1) & HPLC & Dong, 2009 \\
\hline & Nitrogen concentration & & \\
\hline 32-PAHs & $\begin{array}{l}\text { Ultrasonic extraction with methanol } \\
\text { Rotary evaporator andnitrogen } \\
\text { concentration }\end{array}$ & GC-MS & $\begin{array}{l}\text { Saanio et al., } \\
2008\end{array}$ \\
\hline 20 PAHs & $\begin{array}{l}\text { Soxhlet extraction (dichloromethane, }>40 \\
\text { cycles), column chromatography on } \\
\text { Active silica gel. elute with mixture } \\
\text { (n-hexan/dichlorornethane }=3: 1 \text { ) }\end{array}$ & GC-MS & $\begin{array}{l}\text { Lee et al., } \\
2008\end{array}$ \\
\hline 16 EPA-PAHs & $\begin{array}{l}\text { Ultrasonic extraction with } \\
\text { dichloromethane/acetone (3:1), SPE } \\
\text { extraction }\end{array}$ & GC-MS & $\begin{array}{l}\text { Li et al., } \\
2007\end{array}$ \\
\hline 16 EPA-PAHs & $\begin{array}{l}\text { and concentration } \\
\text { Accelerated Solvent Extractor with } \\
\text { dichloromethane/acetone (1:1), } \\
\text { Turbo Vap } 500 \text { concentration, UV and } \\
\text { fluorescence detection. }\end{array}$ & HPLC & $\begin{array}{l}\text { Ravindra et } \\
\text { al, } 2006\end{array}$ \\
\hline 22 PAHs & $\begin{array}{l}\text { Soxhlet extraction by dichloromethane for } 8 \\
\text { h, evaporate concentration }\end{array}$ & HPLC-UVD & $\begin{array}{l}\text { Kameda et } \\
\text { al., } 2005\end{array}$ \\
\hline & & HPLC-FLD & \\
\hline 18 PAHs & $\begin{array}{l}\text { Ultrasonic extraction with } \\
\text { dichloromethane, centrifugation, } \\
\text { evaporate concentration }\end{array}$ & HPLC-FLD & $\begin{array}{l}\text { Ohura et al., } \\
2004\end{array}$ \\
\hline 16 EPA-PAHs & $\begin{array}{l}\text { Ultrasonic extraction with } \\
\text { dichloromethane, rotary evaporation }\end{array}$ & GC-MS & $\begin{array}{l}\text { Gou et al., } \\
2003\end{array}$ \\
\hline 16 EPA-PAHs & $\begin{array}{l}\text { Mass selective detection HP } 5972 \\
\text { Ultrasonic extraction with dichloromethane } \\
\text { and supercritical fluid extraction }\end{array}$ & GC-MS & $\begin{array}{l}\text { Park et al., } \\
2002\end{array}$ \\
\hline 15 PAHs & $\begin{array}{l}\text { evaporate concentration } \\
\text { Dialysis in hexane for } 48 \mathrm{~h} \text {, silica } \\
\text { gel/alumina column clean-up, elute with }\end{array}$ & GC-MS & $\begin{array}{l}\text { Lohmann et } \\
\text { al., } 2001\end{array}$ \\
\hline 16 EPA-PAHs & $\begin{array}{l}\text { dichloromethane/hexane, GPC clean-up } \\
\text { Ultrasonic extraction with } \\
\text { dichloromethane/acetone }\end{array}$ & RP-HPLC-FLD & $\begin{array}{l}\text { Li and Ro, } \\
2000\end{array}$ \\
\hline & rotary evaporation & & \\
\hline
\end{tabular}




\begin{tabular}{|c|c|c|c|}
\hline 14-PAHs & $\begin{array}{l}\text { Soxhlet extraction using dichloromethane, } \\
\text { methanol, acetone } \\
\text { Nitrogen concentration, mass selective } \\
\text { detector }\end{array}$ & GC-MS & $\begin{array}{l}\text { Odabasi et } \\
\text { al., } 1999\end{array}$ \\
\hline
\end{tabular}

Table 4. Applications of pretreatment and analytical methods for PAHs in particulates

\section{Toxicity}

\subsection{Exposure}

In ambient air, human beings are exposed to PAH vapor or PAHs contained in dust and other particulate matter outdoors or indoors at the home or workplace. Sources of human exposure to PAHs include cigarette smoke, vehicle exhaust, residential heating, agriculture burning, waste incineration, and emissions from industrial processes. According to the United States Agency for Toxic Substances and Disease Registry (ATSDR), main exposures of the U.S. population to PAHs include the inhalation of tobacco smoke, wood smoke, and ambient air with PAHs from traffic emissions and consumption of food containing PAHs.

Predominant sources of PAH pollution at home include residential heating, tobacco smoking, and cooking. Vehicle emissions are also main sources of PAHs in many cities. For some people, the primary exposure to PAHs occurs in the workplace. For example, workers in a coke manufacturing factory receive high exposures to PAHs produced in their workplace.

The inhalation of air containing PAHs can lead to human exposure to PAHs. The exposure of traffic policemen to ambient PAHs is mainly from inhalation of vehicle exhaust and road dust containing PAHs. PAHs can also enter the body via food and water consumption or skin contact. PAHs are transported into all tissues of the human body containing fat. They can be stored in fat, liver and kidneys and can accumulate by repeated and long-term exposures. Smaller amounts are also stored in the spleen, adrenal glands, and ovaries.

\subsection{Carcinogenicity and risk assessment}

Air with high concentrations of PAHs causes many adverse effects on different types of organisms, including plants, birds, and mammals. Some studies reported that there is a significant positive correlation between mortality by lung cancer in humans and exposure to PAHs from exhaust from coke ovens, roofing-tar, and cigarette smoke. Some PAHs have been demonstrated to be carcinogenic in humans and experimental animals, and they are classified as carcinogenic materials by many organizations, including the United States Agency for Toxic Substances and Disease Registry (ATSDR), the International Agency for Research on Cancer (IARC), the Department of Health and Human Services (DHHS), the National Occupation Safety and Health Administration (OSHA), and the US-EPA. Table 6 shows the carcinogen classification of 17 priority PAHs by the IARC, compared to classifications by the DHHS and the US-EPA.

Table 7 shows the relative toxicity of priority PAHs selected by the US-EPA. LMW PAHs, except naphthalene, usually are associated with relatively lower toxicity (cancer risk) than HMW PAHs with 5 or 6 aromatic rings. Many toxicity studies reported that benzo[a]pyrene $(\mathrm{BaP})$ has the highest carcinogenic potency with long-term persistency in the environment. Shulte et al. (1993) found a significant increase in all lung tumors and a dose-dependent increase in malignant lung tumors for mice exposed to PAH-enriched exhausts containing 
0.05 or $0.09 \mathrm{mg} / \mathrm{m}^{3} \mathrm{BaP} . \mathrm{BaP}$ is often used as an indicator of human exposure to PAHs, and the toxicity of other PAHs is converted into toxicity equivalency factors (TEFs) to $\mathrm{BaP}$ to evaluate their relative toxicities. Methods using TEFs and the $\mathrm{BaP}$ as a surrogate are more or less similar to each other, except for not requiring expensive monitoring. However, comparative potency methods are quite different from the previous two methods.

\begin{tabular}{|l|l|l|l|}
\hline PAHs & EPA & IARC & DHHS \\
\hline Acenaphthene & & & \\
Anthaphthylene & Not classifiable & & \\
Benz(a)anthracene & Not classifiable & Not classifiable & \\
Benzo(a)pyrene & Probably Carcinogen & Probably Carcinogen & Animal Carcinogen \\
Benzo(b)fluoranthene & Probably Carcinogen & Probably Carcinogen & Animal Carcinogen \\
Benzo(e)pyrene & Probably Carcinogen & Possibly Carcinogen & Animal Carcinogen \\
Benzo(ghi)perylene & Not classifiable & Not classifiable & \\
Benzo(j)fluoranthene & Not included & Possibly Carcinogen & Animal Carcinogen \\
Benzo(k)fluoranthene & Probably Carcinogen & Possibly Carcinogen & \\
Chrysene & Probably Carcinogen & Not classifiable & \\
Dibenz(ah)anthracene & Probably Carcinogen & & Animal Carcinogen \\
Fluoranthene & Not classifiable & Not classifiable & \\
Fluorene & Not classifiable & Not classifiable & Animal Carcinogen \\
Ideno(1,2,3-cd)pyrene & Probably Carcinogen & Possibly Carcinogen & \\
Phenanthrene & Not classifiable & Not classifiable & \\
Pyrene & Not classifiable & IARC in comparing & \\
\hline
\end{tabular}

Table 6.17 priority PAHs were classified by the IARC in comparing those by the DHHS and the US-EPA 


\begin{tabular}{|c|c|c|c|c|c|c|c|}
\hline & $\begin{array}{c}\text { Krewski } \\
\text { et al., } \\
1989\end{array}$ & $\begin{array}{c}\text { Nisbet } \\
\text { and } \\
\text { LaGoy, } \\
1992\end{array}$ & $\begin{array}{c}\text { USEPA, } \\
1993\end{array}$ & $\begin{array}{c}\text { Malcom } \\
\text { and } \\
\text { Dobson, } \\
1994\end{array}$ & $\begin{array}{c}\text { OEHHA, } \\
1994\end{array}$ & $\begin{array}{l}\text { Kalberlah } \\
\text { et al., } 1995\end{array}$ & $\begin{array}{l}\text { McClure and } \\
\text { Schoeny, } 1995\end{array}$ \\
\hline Route & $\begin{array}{c}\text { Not } \\
\text { specified }\end{array}$ & Multiple & Dermal & $\begin{array}{c}\text { Not } \\
\text { specified }\end{array}$ & Inhalation & Multiple & Subcutaneous \\
\hline Acenaphthene & & 0.001 & & 0.001 & & 0.001 & \\
\hline Acenaphthylene & & 0.001 & & 0.001 & & 0.01 & \\
\hline Anthanthrene & 0.32 & & & & & & \\
\hline Benz(a)anthracene & 0.145 & 0.1 & 0.1 & 0.1 & 0.1 & 0.1 & 0.1 \\
\hline Benzo(a)pyrene & 1 & 1 & 1 & 1 & 1 & 1 & 1 \\
\hline Benzo(b)fluoranthene & 0.141 & 0.1 & 0.1 & 0.1 & 0.1 & 0.1 & 0.1 \\
\hline Benzo(e)pyrene & 0.004 & & & 0.01 & & & \\
\hline Benzo(ghi)perylene & 0.022 & 0.01 & & 0.01 & & 0.01 & \\
\hline Benzo(f)fluoranthene & & & 0.1 & & 0.1 & 0.1 & 0.1 \\
\hline Benzo(k)fluoranthene & 0.061 & 0.1 & 0.1 & 0.1 & 0.1 & 0.1 & 0.1 \\
\hline Chrysene & 0.0044 & 0.01 & 0.1 & 0.01 & 0.01 & 0.01 & 0.1 \\
\hline Coronene & & 0.001 & & & & & \\
\hline Cyclopenta(cd)pyrene & 0.023 & 0.1 & 0.1 & & & & 0.1 \\
\hline Dibenzo(a,e)pyrene & & & 1 & & 1 & & 1 \\
\hline Dibenz $(a, c)$ anthracene & & 0.1 & & & & & \\
\hline Dibenz(ah)anthracene & 1.11 & 1 & 1 & 1 & 0.4 & 1 & 1 \\
\hline Dibenzo(a,e)pyrene & & & 100 & & 10 & & 100 \\
\hline Dibenzo(a,h)pyrene & & & 1 & & 10 & & 1 \\
\hline Dibenzo(a,i)pyrene & & & 0.1 & & & & 0.1 \\
\hline Dibenzo(a,l)pyrene & & & & & 10 & & \\
\hline Fluoranthene & & 0.001 & & 0.001 & & 0.01 & \\
\hline Fluorene & & 0.001 & & 0.001 & & 0 & \\
\hline Ideno(1,2,3-cd)pyrene & 0.232 & 0.1 & 0.1 & 0.1 & 0.1 & 0.1 & 0.1 \\
\hline
\end{tabular}


Naphthalene

Perylene

Phenanthrene

Pyrene

0.81
0.001

0.001

0.001

0.001

0

0.001

Table 7. Proposed TEFs for individual PAHs (Modified from Knafla et al., 2006) 


\subsection{Toxicity equivalency factors (TEFs)}

TEF evaluation is the most popular method used to identify the toxicity of PAHs. TEFs of individual PAHs have been reported by many researchers (Table 7). Toxicity equivalency concentrations (TEQs) are calculated as the product of summing up the values obtained by TEF values and concentrations of PAHs, as follows:

$\mathrm{TEQ}=\Sigma\left(\mathrm{C}_{\mathrm{i}} \times \mathrm{TEF}_{\mathrm{i}}\right)$

Where,

TEQ: toxic equivalent concentration

$\mathrm{C}_{\mathrm{i}}$ : concentration of $\mathrm{PAH}_{\mathrm{i}}$.

Petry et al. (1995) used TEFs in assessing occupational and environmental health risks associated with exposure to airborne mixtures of PAHs. They used information of the ratio between airborne concentrations of $\mathrm{BaP}$ equivalents to the concentrations of $\mathrm{BaP}$ alone, which can indicate the variation of risk for the different environments. Individual PAH-based $\mathrm{BaP}_{\text {eq }}$ toxicity estimates were up to one order of magnitude higher than estimates based on $\mathrm{BaP}$ concentration measurements and BaP-risk from risk assessment of lung cancer related to occupational exposure (Vyskocil et al., 2004; Yanjual et al., 2007). Yajuan et al. (2008) reported that $1.73 \%$ of the cancer sufferers of Beijing inhabitants in 2007 were related to inhalation of PAHs in ambient air. There is an increasing trend of the cancer risk of residents by inhalation of ambient air containing hazardous air pollutants (HAPs), such as PAHs.

Halek et al. (2008) estimated that the annual number of lung cancer cases attributable to carcinogenic PAH compounds in 2005 was 58 persons per million. The $\mathrm{BaP}$ is the highest carcinogenic contributor, followed by DahA, Ind and BbF (Pufulete et al., 2004). However, DahA was suggested as a new surrogate compound to measure the toxicity of particle phase-PAHs because its toxicity is almost equal to that of BaP. While estimating the toxicity of PAHs in road dust of Ulsan, Korea, Dong and Lee (2009) found a significant correlation coefficient between TEQ and total PAH concentrations.

\section{Introduction of Nitro-PAHs}

Nitrated polycyclic aromatic hydrocarbons (N-PAHs) are an important category of derivations of PAHs and are of special interest because they include potential mutagens and carcinogens. They have been recognized as direct-acting mutagens and carcinogens to mammalian systems and are, thus, considered to have far greater toxicity than unsubstituted PAHs (Pedersen et al., 1998; Atkinson and Arey, 1994). Nitro-PAHs are formed mainly from incomplete combustion processes or by the reaction of PAH with atmospheric oxidants, such as dinitrogen pentoxide, nitrogen trioxide, and oxygen radicals in the presence of nitrogen oxides (Atkinson et al., 1990; Fan et al., 1995; Enya et al., 1997; Environmental Heath Criteria-EHC, 2003).

Nitro-PAHs occur as a mixture with parent PAHs in the vapor phase or adsorbed onto particulate matter in the atmosphere. Two-ring N-PAHs, such as nitronaphthalenes, are the dominant N-PAHs in the vapor phase. However, N-PAHs, which include nitro derivatives of pyrene, fluoranthene, anthracene, chrysene, and others, tend to condense on particle surfaces because of their low vapor pressure. Atmospheric lifetimes of N-PAHs are affected 
by photolysis and gas-phase reactions with hydroxyl and nitrate radicals and with ozone under atmospheric conditions. Photolysis is the dominant loss process for N-PAHs (e.g. 1-and 2-nitronaphthalene). "Particle oxidation of nitro-PAHs by ozone may be the main loss process at night" (EHC, 2003).

$\mathrm{N}-\mathrm{PAHs}$ in the environment originate from direct emissions from combustion sources and nitration of unsubstituted PAHs. Main sources include vehicle exhaust (particularly diesel), industrial emissions, and domestic emissions (residential heating/cooking and wood burning), as with unsubstituted PAHs. In urban areas, N-PAH pollution is predominantly caused by diesel engine vehicle traffic and residential heating. Indoor human exposure to nitro-PAHs is from kerosene heating and use of cooking oil. Effects of N-PAHs on human health have been estimated based on the data of carcinogenic effects for 28 N-PAHs. Tokiwa et al. (1998 and 2000) reported that N-PAHs have been detected in samples of resected lung tissue from patients in Japan.

Sampling methods of nitro-PAHs are similar to those of unsubstituted PAHs. Most nitro-PAH samples are collected on sorbent (PUF) or XAD-2 resins and filters by high-volume samplers. Then, nitro-PAH samples undergo extraction, clean up, and analysis. However, there are problems which affect atmospheric sampling and measurement of N-PAHs. These issues include: 1) N-PAHs are emitted in a very complex matrix; 2) concentrations of N-PAHs are very low and only detected using highly sensitive analytical methods; and 3) formation of N-PAHs is strongly influenced by meteorological conditions, such as sunlight radiation, humidity, and concentrations of ambient contaminants, such as ozone, nitrogen oxides, and photooxidants.

\section{References}

Aakinson, R.; Arey, J.; Zielinska, B. \& Aschmann, S.M. (1990). Kinetics and nitro-products of gas-phase $\mathrm{OH}$ and $\mathrm{NO} 3$ radical-initiated reactions of naphthalene, fluoranthene and pyrene. International Journal of Chemical Kinetics, 22., 999-1014.

Abrantes, R.; Assunção, J.V. \& Nóbrega, R.B. (2004). Emission of polycyclic aromatic hydrocarbons from light-duty diesel vehicles exhaust. Atmospheric Environment, 38., 1631-1640.

Abrantes, R.; Assunção, J.V.; Pesquero, C.R.; Bruns, R.E. \& Nóbrega, R.B. (2009). Emission of polycyclic aromatic hydrocarbons from gasohol and ethanol vehicles. Atmospheric Environment, 43., 648-654.

Atkinson, R. \& Arey, J. (1994). Atmospheric chemistry of gas-phase polycyclic aromatic hydrocarbons: formation of atmospheric mutagens. Environmental Health Perspectives, 102., 117-126.

ATSDR (Agency for Toxic Substances and Disease Registry). (1995). Toxicological profile for polycyclic aromatic hydrocarbons (PAHs). US Department of Health and Human Services, Public Health Service. Atlanta, GA. http://www. atsdr.cdc.gov/toxprofiles/tp69.html.

Australian government, 1999. Technical report No. 2: Polycyclic aromatic hydrocarbons (PAHs) in Australia. Department of the environment and heritage, Australia.

Baek, S.; Goldstone, M.; Kirk, P.; Lester, J. \& Perry, R. (1991). Phase distribution and particle size dependency of polycyclic aromatic hydrocarbons in the urban atmosphere. Chemosphere, 22., 503-520. 
Caslavsky, J.; Kotlarikova, P. \& Benesova, K. (2004). Sampling of airborne polycyclic aromatic hydrocarbons with semipermeable membrane devices. Environental Chemical Letture, 2., 89-92.

Chen, S.; Su, B.; Chang, J.E.; Lee, W.J.; Huang, K.L.; Hsieh, L.T.; Huang, J.C.; Lin, W.J. \& Lin, C.C. (2007). Emissions of polycyclic aromatic hydrocarbons (PAHs) from the pyrolysis of scrap tires. Atmospheric Environment, 41., 1209-1220.

Chen, S.J.; Su, H.B.; Chang, J.E.; Lee,W.J.; Huang, K.L.; Hsieh, L.T.; Huang, Y.C.; Lin, W.Y. \& Lin, C.C. (2007). Emissions of polycyclic aromatic hydrocarbons (PAHs) from the pyrolysis of scrap tires. Atmospheric Environment, 41., 1209-1220.

Chen, Y.-C.; Lee, W.-J.; Uang, S.-N.; Lee, S.-H. \& Tsai, P.-J. (2006). Characteristics of polycyclic aromatic hydrocarbon (PAH) emissions from a UH-1H helicopter engine and its impact on the ambient environment. Atmospheric Environment, 40., 7589-7597.

Chen, Y.; Bi, X.; Mai, B.; Sheng, G. \& Fu, J. (2004). Emission characterization of particulate/gaseous phases and size association for polycyclic aromatic hydrocarbons from residential coal combustion. Fuel, 83., 781-790.

Cotham, W.E. \& Bidleman, T.F. (1995). Polycyclic Aromatic Hydrocarbons and Polychlorinated Biphenyls in air at an urban and a rural site near Lake Michigan. Environmental Science \& Technology, 29., 2782 - 2789.

Dong, T.T.T. \& Lee, B.K. (2009). Characteristics, toxicity, and source apportionment of polycyclic aromatic hydrocarbons (PAHs) in road dust of Ulsan, Korea. Chemosphere, 74., 1245-1253.

Environmental Health Criteria (EHC) 229. (2003). Selecteed nitro- and nitro-oxy-polycyclic aromatic hydrocarbon. WHO Library:

http://whqlibdoc.who.int/ehc/WHO_EHC_229.pdf.

European communities. (2001). Ambient air pollution by polycyclic aromatic hydrocarbons (PAHs) - Position paper.

Fabbri, D. \& Vassura, I. (2006). Evaluating emission levels of polycyclic aromatic hydrocarbons from organic materials by analytical pyrolysis. Journal of Analytical and Applied Pyrolysis, 75., 150-158.

Fan, Z.; Chen, D.; Birla, P. \& Kamens, R.M. (1995). Modeling of nitro-polycyclic aromatic hydrocarbon formation and decay in the atmosphere. Atmospheric Environment, 29., 1171-1181.

Fang, G.C.; Chang, K.F.; Lu, C. \& Bai, H. (2004). Estimation of PAHs dry deposition and BaP toxic equivalency factors (TEFs) study at urban, industry park and rural sampling sites in central Taiwan, Taichung. Chemosphere, 44., 787-796.

Fang, G.C.; Wu, Y.S.; Fu, P.P.C.; Yang, I.L. \& Chen, M.H. (2004). Polycyclic aromatic hydrocarbons in the ambient air of suburban and industrial regions of central Taiwan. Chemosphere, 54., 443-452.

Fang, G.C.; Chang, C.N.; Wu, Y.S.; Fu, P.P.C.; Yang., I.L. \& Chen, M.H. (2004). Characterization, identification of ambient air and road dust polycyclic aromatic hydrocarbons in central Taiwan, Taichung. Science of The Total Environment, 327., 135-146.

Fang, G.C.; Chang, K.F.; Lu, C. \& Bai, H. (2002). Toxic equivalency factors study of polycyclic aromatic hydrocarbons (PAHs) in Taichung city, Taiwan. Toxicology and Industrial Health, 18., 279-288. 
Fertmann, R.; Tesseraux, I.; Schümann, M. \& Neus, H. (2002). Evaluation of ambient air concentrations of polycyclic aromatic hydrocarbons in Germany from 1990 to 1998. Journal of exposure analysis and environmental epidemiology, 12., 115-123.

Gambino, M.; Iannaccone, S.; Prati, M.V. \& Unich, A. (2000). Regulated and unregulated emissions reduction with retrofit catalytic after-treatment on small two stroke S.I. engine. SAE Technical Paper Series 2000-01-1846. International Spring Fuels \& Lubricants Meeting \& Exposition, June 19-22, Paris, France.

Guo, H.; Lee, S.C.; Ho, K.F.; Wang, X.M. \& Zou, S.C. (2003). Particle-associated polycyclic aromatic hydrocarbons in urban air of Hong Kong. Atmospheric Environment, 37., 5307-5317.

Gupta, S.; Saksena, S.; Shankar, V.R. \& Joshi, V. (1998). Emission factors and thermal efficiencies of cooking biofuels from developing countries. Biomass and Bioenergy, 14., 547-559.

Harrison, R.M.; Smith, D.J.T. \& Luhana, L. (1996). Source Apportionment of Atmospheric Polycyclic Aromatic Hydrocarbons Collected from an Urban Location in Birmingham, U.K. Environmental Science \& Technology, 30., 825 -832.

He, C.; Ge, Y.; Tan, Y.; You, K.; Han, X. \& Wang, J. (2010). Characteristics of polycyclic aromatic hydrocarbons emissions of diesel engine fueled with biodiesel and diesel. Fuel, In Press, Uncorrected Proof.

IARC (International Agency for Research on Cancer), 1989. IARC monographs on the evaluation of the carcinogenic risk of chemicals to humans: occupational exposures in petroleum refining: crude oil and major petroleum fuels. Volume 45. Lyon.

IPCS (International programe on chemical safely). (1998). http://www.inchem.org/documents/ehc/ehc/ehc202.htm\#SubSectionNumber:5.1.1

Jenkins, B.M.; Jones, A.D.; Turn, S.Q.; Williams, R.B. (1996). Emission factors for polycyclic aromatic hydrocarbons from biomass burning. Environmental Science and Technology, 30., 2462-2469.

Kameda, Y.; Shirai, J.; Komai, T.; Nakanishi, J. \& Masunaga, S. (2005). Atmospheric polycyclic aromatic hydrocarbons: size distribution, estimation of their risk and their depositions to the human respiratory tract. Science of The Total Environment, 340., 71-80.

Knafla, A.; Phillipps, K.A.; Brecher, R.W.; Petrovic, S. \& Richardson, M. (2006). Development of a dermal cancer slope factor for benzo[a]pyrene. Regulatory Toxicology and Pharmacology, 45., 159-168.

Lee, B.K. \& Lee, C.B. (2004). Development of an improved dry and wet deposition collector and the atmospheric deposition of PAHs onto Ulsan Bay, Korea. Atmospheric Environment, 38., 863-871.

Lee, J.Y.; Kim, Y.P.; Kaneyasu, N.; Kumata, H. \& Kang, C.H. (2008). Particulate PAHs levels at Mt. Halla site in Jeju Island, Korea: Regional background levels in northeast Asia. Atmospheric Research, 90., 91-98.

Lee, W. J.; Wang, Y. F.; Lin, T. C.; Chen, Y. Y.; Lin, W. C.; Ku, C. C. \& Cheng, J.T. (1995). PAH characteristics in the ambient air of traffic-source. The Science of the Total Environment, 159., 185-200.

Lee, W.J.; Liow, M.C.; Tsai, P.J. \& Hsieh, L.T. (2002). Emission of polycyclic aromatic hydrocarbons from medical waste incinerators. Atmospheric Environment, 36.,781-790 
Li, C.S. \& Ro, Y.S . (2000). Indoor characteristics of polycyclic aromatic hydrocarbons in the urban atmosphere of Taipei. Atmospheric Environment, 34., 611-620.

Li, C.T.; Mi, H.H.; Lee, W.J.; You, W.C. \& Wang, Y.F. (1999). PAH emission from the industrial boilers. Journal of Hazardous Materia, 1 69., 1-11.

Li, K.; Li, H.; Liu, L.; Hashi, Y.; Maeda, T. \& Lin, J.M. (2007). Solid-phase extraction with C30 bonded silica for analysis of polycyclic aromatic hydrocarbons in airborne particulate matters by gas chromatography-mass spectrometry. Journal of Chromatography A, 1154., 74-80.

Li, Z.; Sjodin, A.; Porter, E.N.; Patterson D.G.; Needham, L.L.; Lee, S.L.; Russell, A.G. \& Mulholland, J.A. (2009). Characterization of PM2.5-bound polycyclic aromatic hydrocarbons in Atlanta. Atmospheric Environment, 43., 5., 1043-1050.

Lim, C.H.M.; Ayoko, G.A. \& Morawska,. L. (2005). Characterization of elemental and polycyclic aromatic hydrocarbon compositions of urban air in Brisbane. Atmospheric Environment, 39., 463-476.

Liu, W.X.; Dou, H.; Wei, Z.W.; Chang, B.; Qui, W.X.; Liu, Y. \& Shu, T. (2008). Emission characteristics of polycyclic aromatic hydrocarbons from combustion of different residential coals in North China. Science of the total environment, 407., 1436-1446.

Liu, W.X.; Dou, H.; Wei, Z.W.; Chang, B.; Qui, W.X.; Liu, Y. \& Shu, T. (2008). Emission characteristics of polycyclic aromatic hydrocarbons from combustion of different residential coals in North China. Science of the total environment, 407., 1436-1446.

Lohmann, R.; Comgan, B.P.; Howsam, M.; Jones, K.C. \& Ockenden, W.A. (2001). Further developments in the use of semipermeable membrane devices (SPMDs) as passive air samplers for persistent organic pollutants: field application in a spatial survey of PCDD/Fs and PAHs[J]. Environtal Scicence andTechnology, 35., 2576- 2582.

Lu, H.; Zhu, L. \& Zhu, N. (2009). Polycyclic aromatic hydrocarbon emission from straw burning and the influence of combustion parameters. Amospheric Environment, 43., 978-983.

Oanh, N.T.K.; Reutergardh, L.B. \& Dung, N.T. (1999). Emission of polycyclic aromatic hydrocarbons and particulate matter from domestic combustion of selected fuels. Environmental Science and Technology, 33., 2703-2709.

Odabasi, M.; Vardar, N.; Sofuoglu, A.; Tasdemir, Y. \& Holsen, T.M. (1999). Polycyclic aromatic hydrocarbons (PAHs) in Chicago air. The Science of The Total Environment, 227., 57-67.

Ohura, T.; TAmagai, T.; Sugiyama, T.; Fusaya, M. \& Matsushita, H. (2004). Characteristics of particle matter and associated polycyclic aromatic hydrocarbons in indoor and outdoor air in two cities in Shizuoka, Japan. Atmospheric Environment, 38., 2045-2054.

Okuda, T.; Okamoto, K.; Tanaka, S.; Shen, Z.; Han, Y. \& Huo, Z. (2010). Measurement and source identification of polycyclic aromatic hydrocarbons (PAHs) in the aerosol in Xi'an, China, by using automated column chromatography and applying positive matrix factorization (PMF). Science of The Total Environment, 408., 8., 1909-1914.

Omar, N.Y.; Mon, T.C.; Rahman, N.A. \& Abas, M.R.B. (2006). Distributions and health risks of polycyclic aromatic hydrocarbons (PAHs) in atmospheric aerosols of Kuala Lumpur, Malaysia. Science of The Total Environment, 369., 76-81.

Park, S.S.; Kim, Y.J. \& Kang, C.H. (2002). Atmospheric polycyclic aromatic hydrocarbons in Seoul, Korea. Atmospheric Environment, 36, 2917-2924. 
Pedersen, D.U.; Durant, J.L.; Penman, B.M.; Crespi, C.L.; Hemond, H.F.; Lafleur A.L. \& Cass, G.R. (2004). Human-cell mutagens in respirable airborne particles in the northeastern United States. 1. Mutagenicity of fractionated samples. Environmental Science and Technology, 38., 682-689.

Pedersen, D.U.; Durant, J.L.; Taghizadeh, K.; Hemond, H.F.; Lafleur A.L. \& Cass, G.R. (2005). Human cell mutagens in respirable airborne particles from the Northeastern United States. 2. Quantification of mutagens and other organic compounds. Environmental Science and Technology, 39., 9547-9560.

Petry, T.; Schmid, P. \& Schlater, C. (1996). The use of toxic equivalency factors in assessing occupational and environmental health risk associated with exposure to airborne mixtures of polycyclic aromatic hydrocarbons (PAHs). Chemosphere, 32., 639-648.

Poppi, N.R. \& Silva, M.S. (2005). Polycyclic aromatic hydrocarbons and other selected organic compounds in ambient air of Campo Grande City, Brazil. Atmospheric Environment, 39., 2839-2850.

Pufulete, M.; Battershill, J.; Boobis, A. \& Fielder, R. (2004). Approaches to carcinogenic risk assessment for polycyclic aromatic hydrocarbons: a UK perspective. Regulatory Toxicology and Pharmacology, 40., 54-66.

Ravindra, K.; Bencs, L.; Wauters, E.; de Hoog, J.; Deutsch, F.; Roekens, E.; Bleux, N.; Bergmans, P. \& Van Grieken, R. (2006a). Seasonal and site specific variation in vapor and aerosol phase PAHs over Flanders (Belgium) and their relation with anthropogenic activities. Atmospheric Environment, 40., 771-785.

Ravindra, K.; Sokhi. R. \& Grieken, R.V. (2008). Atmospheric polycyclic aromatic hydrocarbons: Source attribution, emission factors and regulation. Atmospheric Environment, 42., 2895-2921.

Ravindra, K.; Wauters, E.; Taygi, S.K.; Mor, S. \& Van Grieken,R. (2006b). Assessment of air quality after the implementation of CNG as fuel in public transport in Delhi, India. Environmental Monitoring and Assessment, 115., 405-417

Saarnio, K.; Sillanpää, M.; Hillamo, R.; Sandell, E.; Pennanen, AS. \& Salonen, R.O. (2008). Polycyclic aromatic hydrocarbons in size-segregated particulate matter from six urban sites in Europe. Atmospheric Environment, 42., 9087-9097

Sasaki, J.; Aschmann, S.M.; Kwok, E.S.C.; Atkinson, R. \& Arey, J. (1997). Products of the gas-phase $\mathrm{OH}$ and $\mathrm{NO} 3$ radical-initiated reactions of naphthalene. Environmental Science and Technology, 31., 3173-3179.

Schauer, J.J.; Kleeman,M.J.; Cass, G.R. \& Simoneit, B.R.T. (2001). Measurement of emissions from air pollution sources, 3. C1-C29 organic compounds from fireplace combustion of wood. Environmental Science and Technology, 35., 1716-1728.

Sharma, H.; Jain, V.K. \& Khan, Z.H. (2007). Characterization and source identification of polycyclic aromatic hydrocarbons (PAHs) in the urban environment of Delhi. Chemosphere, 66., 302-310.

Sienra, M.R.; Rosazza, N.G. \& Préndez, M. (2005). Polycyclic aromatic hydrocarbons and their molecular diagnostic ratios in urban atmospheric respirable particulate matter. Atmospheric Research, 75., 267-281.

Spezzano, P.; Picini, P.; Cataldi, D.; Messale, F. \& Manni., C. (2008). Particle- and gas-phase emissions of polycyclic aromatic hydrocarbons from two-stroke, 50-cm3 mopeds. Atmospheric Environment, 42.,18., 4332-4344 
Tokiwa, H. \& Ohnishi, Y. (1986). Mutagenicity and carcino-genicity of nitroarenes and their sources in the environment. Critical Reviews in Toxicology, 17., 23-60.

Tokiwa, H.; Nakanishi, Y.; Sera,N.; Hara, N. \& Inuzuka, S. (1998). Analysis of environmental carcinogens associated with the incidence of lung cancer. Toxicology Letters, 99., 33-41

US EPA. (1995). Toxicological profile for polycyclic aromatic hydrocarbons. US department of health and human services.

Vasilakos, Ch.; Levi, N.; Maggos, Th.; Hatzianestis, J.; Michopoulos, J. \& Helmis, C. (2007). Gas-particle concentration and characterization of sources of PAHs in the atmosphere of a suburban area in Athens, Greece. Journal of Hazardous Materials, 140., 45-51.

Venkataraman, C.; Negi, G.; Sardar, S.B. \& Rastogi, R. (2002). Size distributions of polycyclic aromatic hydrocarbons in aerosol emissions from biofuel combustion. Aerosol Science, 33., 503-518.

Wan, X.; Chen, J.; Tian, F.; Sun, W.; Yang, F. \& Saiki, K. (2006). Source apportionment of PAHs in atmospheric particulates of Dalian: Factor analysis with nonnegative constraints and emission inventory analysis. Atmospheric Environment, 40., 6666-6675.

Yang, H.H.; Hsieh, L.T.; Liu, H.C. \& M, H.H. (2005). Polycyclic aromatic hydrocarbon emissions from motorcycles. Atmospheric Environment, 39., 17-25.

Yang, H.H.; Jung, R.C.; Wang, Y.F. \& Hsieh, L.T. (2005). Polycyclic aromatic hydrocarbon emissions from joss paper furnaces. Atmospheric Environment, 39., 3305-3312.

Yang, H.H.; Lee, W.J.; Chen, S.J. \& Lai, S.O. (1998). PAH emission from various industrial stacks. Journal of Hazardous Materials, 60., 159-174.

Zhang, Y. \& Tao, X. (2009). Global atmospheric emission inventory of polycyclic aromatic hydrocarbons (PAHs) for 2004. Atmospheric Environment, 43., 812-819.

Zhu, L., Lu, H.; Chen, S. \& Amagai, T. (2009). Pollution level, phase distribution and source analysis of polycyclic aromatic hydrocarbons in residential air in Hangzhou. China Journal of Hazardous Materials, 162., 1165-1170. 


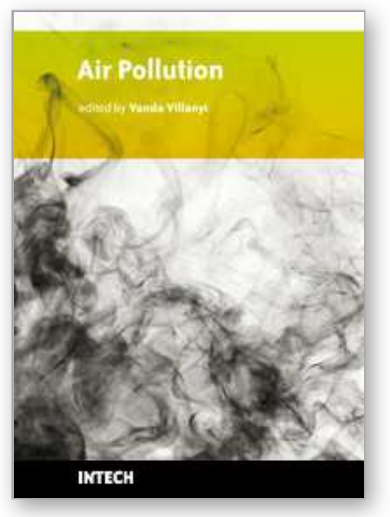

\author{
Air Pollution \\ Edited by Vanda Villanyi
}

ISBN 978-953-307-143-5

Hard cover, 370 pages

Publisher Sciyo

Published online 17, August, 2010

Published in print edition August, 2010

Although the climate of the Earth is continually changing from the very beginning, anthropogenic effects, the pollution of the air by combustion and industrial activities make it change so quickly that the adaptation is very difficult for all living organisms. Researcher's role is to make this adaptation easier, to prepare humankind to the new circumstances and challenges, to trace and predict the effects and, if possible, even decrease the harmfulness of these changes. In this book we provide an interdisciplinary collection of new studies and findings on the score of air pollution.

\title{
How to reference
}

In order to correctly reference this scholarly work, feel free to copy and paste the following:

Byeong-Kyu Lee (2010). Sources, Distribution and Toxicity of Polyaromatic Hydrocarbons (PAHs) in Particulate Matter, Air Pollution, Vanda Villanyi (Ed.), ISBN: 978-953-307-143-5, InTech, Available from:

http://www.intechopen.com/books/air-pollution/sources-distribution-and-toxicity-of-polyaromatic-hydrocarbonspahs-in-particulate-matter

\section{INTECH}

open science | open minds

\section{InTech Europe}

University Campus STeP Ri

Slavka Krautzeka 83/A

51000 Rijeka, Croatia

Phone: +385 (51) 770447

Fax: +385 (51) 686166

www.intechopen.com

\section{InTech China}

Unit 405, Office Block, Hotel Equatorial Shanghai

No.65, Yan An Road (West), Shanghai, 200040, China

中国上海市延安西路65号上海国际贵都大饭店办公楼405单元

Phone: +86-21-62489820

Fax: +86-21-62489821 
(C) 2010 The Author(s). Licensee IntechOpen. This chapter is distributed under the terms of the Creative Commons Attribution-NonCommercialShareAlike-3.0 License, which permits use, distribution and reproduction for non-commercial purposes, provided the original is properly cited and derivative works building on this content are distributed under the same license. 